\title{
CAT CENTER DI BANJARBARU
}

\author{
Mira Rizmia Lizara \\ Program Studi Teknik Arsitektur Fakultas Teknik Universitas Lambung Mangkurat \\ h1b115214@mhs.ulm.ac.id
}

\author{
Dahliani \\ Program Studi Teknik Arsitektur Fakultas Teknik Universitas Lambung Mangkurat \\ dahliani.teknik@ulm.ac.id
}

\begin{abstract}
ABSTRAK
Cat Center di Banjarbaru merupakan tempat dimana kucing dan manusia dapat saling berinteraksi. Kucing merupakan hewan yang paling diminati untuk dijadikan peliharaan rumah, komunitas pecinta hewan maupun individu pemelihara hewan bermunculan dan berkumpul berbagi kesamaan minatnya terhadap hewan kucing, karena tidak adanya wadah bagi peminat atau komunitas pecinta hewan untuk membawa hewan mereka berjalan-jalan maupun berkumpul sebagai sesama pecinta hewan kucing. Maka diperlukan tempat khusus untuk memelihara khususnya hewan kucing dan memeliharanya, disebut tempat yang pet friendly-human friendly. Tujuan dari perancangan cat center di Banjarbaru ini menyediakan wadah dan fasilitas berdasar kebutuhan yang dapat menunjang manusia dan hewan untuk berinteraksi. Metode desain yang digunakan untuk perancangan cat center ini dengan menganalisis karakter yang dimiliki kucing kemudian diterapkan dalam konsep yaitu attractive dimana konsep ini merupakan penggabungan dari berbagai karakter atau perilaku yang dimiliki kucing, yakni: kelakuan kucing yang menyenangkan dan terkadang bertingkah aneh yang merupakan point of interest kucing, keingintahuannya tinggi, bersahabat, aktif dan suka bermain. Dari konsep tersebut desain yang akan diterapkan merupakan ruang dimana kucing dan manusia dapat berinteraksi juga dimana kucing akan merasa nyaman bermain di setiap sudut ruangnya. Cat center di Banjarbaru ini merupakan bangunan publik dengan Jenis ruang massa banyak yang disesuaikan berdasar sifat maupun fungsi ruang. Ruang interaksi pada kawasan dengan perwujudan fasilitas-fasilitas yang saling terhubung antara satu dengan lainnya.
\end{abstract}

Kata kunci: kucing, karakter, fasilitas.

\section{ABSTRACT}

Cat Center in Banjarbaru is a place where cats and humans can interact with each other. Cats are the most in-demand animals to be home pets, the community of animal lovers and individual animal keepers sprung up and gathered to share their similar interest in cat animals, because there is no container for animal lovers or communities to take their animals for a walk or gathering as fellow cat lovers. Therefore, a special place is needed for keepers, especially cat animals and their keepers, called pet friendly-human friendly places. The purpose of the design of the paint center in Banjarbaru is to provide containers and facilities based on the needs that can support humans and animals to interact. The design method used for the design of this cat center by analyzing the character owned by the cat is then applied in the concept that is attractive where the concept is a combination of various characters or behaviors that cats have, namely: pleasant and sometimes strange cat behavior 
that is the point of interest of the cat, its curiosity is high, friendly, active and playful. From the concept, the design that will be applied is a space where cats and humans can interact as well where the cat will feel comfortable playing in every corner of the room. Cat center in Banjarbaru is a public building with many types of mass space that are customized based on the nature or function of the space. Interaction space in the area with the embodiment of facilities that are interconnected with each other.

Keywords: cats, characters, facility.

\section{PENDAHULUAN}

Hewan telah hidup berdampingan dengan manusia sejak lama dan mengalami perubahan fungsi bagi manusia. Minat manusia sekarang menjadikan hewan sebagai peliharaan, therapy, hobi, teman hidup, penjaga, maupun sebagai hiburan, tidak sekedar itu, hewan menjadi bagian dari kehidupan penting sebagian manusia dan dilibatkan dalam berbagai aktivitas.

Menurut penelitian, memelihara atau berinteraksi dengan hewan dapat memberikan manfaat psikologis maupun kesehatan fisik (Stephen J. O'Brien), mengenalkan hewan kepada anak-anak juga dapat memberikan dampak positif membantu perkembangan anak menjadi lebih aktif, mengajarkan tanggung jawab, melatih hubungan sosial dan empati. Hubungan yang terjalin lama antara manusia dan hewan peliharaan dapat membentuk ikatan emosional tersendiri, tidak sekedar menyalurkan kasih sayang dari sentuhan, bermain, bercakap, memelihara hewan aktif membuat pemilik aktif bergerak, menawar rasa kesepian dan menyalurkan bahagia. Orang yang memiliki hewan peliharaan dan memiliki hubungan yang kuat dengan hewan peliharaannya sejatinya akan bertanggung jawab memenuhi kebutuhan yang diperlukan hewan, rela mengeluarkan materi ekstra, meluangkan waktu dan tenaga untuk merawat hewan kesayangannya.

Kebutuhan manusia yang semakin meningkat menuntut orang-orang menjadi sibuk dan tidak memiliki waktu luang untuk merileksasikan diri demi memenuhi kebutuhan, hal itu bisa mengakibatkan rasa jenuh dan stres. Solusi dari menghilangkan rasa jenuh setelah beraktivitas sebagian orang memilih memelihara hewan dan orang-orang yang telah memelihara hewan karena rasa sayang, menganggap mereka sebagai teman hidup mereka kehilangan intensitas interaksi dengan peliharaannya. Hewan peliharaan memiliki kebutuhan-kebutuhan yang mirip dengan manusia, meskipun hewan merupakan makhluk hidup yang mandiri jika mereka sudah terdomestikasi terikat dengan manusia ketika mereka kehilangan sedikit perhatian dari pemilik mereka akan merasa kesepian, kehilangan, stress bahkan dapat menimbulkan penyakit.

Minat memelihara hewan telah menyebar luas termasuk di kota Banjarbaru, pada perkembangannya hewan seperti anjing, ikan, kelinci, kucing, reptile, serangga, unggas merupakan hewan yang sering dijadikan peliharaan maupun ternak. Berdasarkan kuisioner yang dibagikan dan ditanggapi oleh 85 responden yang menetap di wilayah Kota Banjarbaru dengan salah satu pertanyaan yang diajukan "hewan apa yang anda pelihara", berikut hasil yang didapatkan

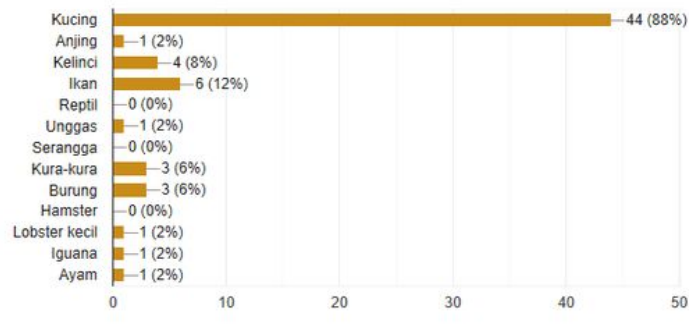

Gambar 1 hewan peliharaan responden di wilayah kota Banjarbaru 
Dari 85 tanggapan yang didapatkan sebanyak 44 responden memelihara kucing, 21 responden memelihara hewan lainnya dan 20 responden lainnya tidak memelihara hewan sama sekali, dari hasil tersebut kucing merupakan hewan yang popular untuk dipelihara oleh kebanyakan orang di wilayah Banjarbaru. Kepopularan kucing sebagai hewan untuk dipelihara dinyatakan dengan munculnya komunitas yang menampung kegiatan para penggemar atau pemelihara kucing yaitu, Indonesian Cat Association (ICA).

Kucing menjadi hewan yang popular dipelihara di Banjarbaru, berdasar data dari Dinas Ketahanan Pangan, Pertanian dan Perikanan kota Banjarbaru pada tahun 2018 jumlah populasi hewan kucing berjumlah 7000 ekor termasuk hewan liar dan berpemilik. Meningkatnya animo masyarakat Banjarbaru terhadap hewan peliharaan kucing dapat dilihat pada event yang diselenggarakan oleh Indonesian Cat Association 21 juli 2019 di atrium qmall berupa perlombaan kucing, ketangkasan kucing, pameran jenis kucing ini diikuti puluhan peserta, event yang serupa juga dilaksanakan tahun lalu berupa sosialisasi pemeliharaan hewan.
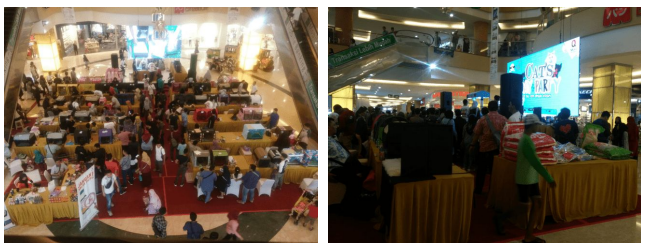

Gambar 2 cat's day party di atrium qmall Banjarbaru

Acara yang dilaksanakan mendapat respon yang positif dari masyarakat, pengunjung yang hadir pun tidak hanya kalangan pemelihara kucing, ada dari kalangan masyarakat yang memiliki ketertarikan terhadap kucing. Hal ini nantinya akan menimbulkan ketertarikan untuk memelihara hewan. Melihat respon masyarakat Banjarbaru terhadap kegiatan yang diadakan ini memunculkan peluang adanya suatu wadah untuk berkumpul dan berbagi ilmu, tempat yang menyediakan fasilitas menunjang kegiatan maupun kebutuhan hewan yang lengkap dalam satu lokasi.

Di kota Banjarbaru perkumpulan atau komunitas pecinta hewan sempat ramai bermunculan seperti komunitas reptile, exotic animals, Kerabat Musang Banjarbaru (KERAMBA), South Borneo Sugar Glider (SBSG), Animal Lovers Kalimantan (ALKA) mereka pada saat itu rutin melakukan perkumpulan pada car free day di lapangan Murjani Banjarbaru, komunitas tersebut berkumpul tidak hanya membawa peliharaan mereka untuk dipamerkan namun juga mensosialisasikan hewan peliharaan mereka ke masyarakat dengan membolehkan masyarakat melihat, menyentuh dan memegangnya. Tidak hanya komunitas, individu pun sering terlihat membawa hewan peliharaan mereka terutama yang memelihara hewan anjing dan kucing berkeliling di lapangan Murjani Banjarbaru.
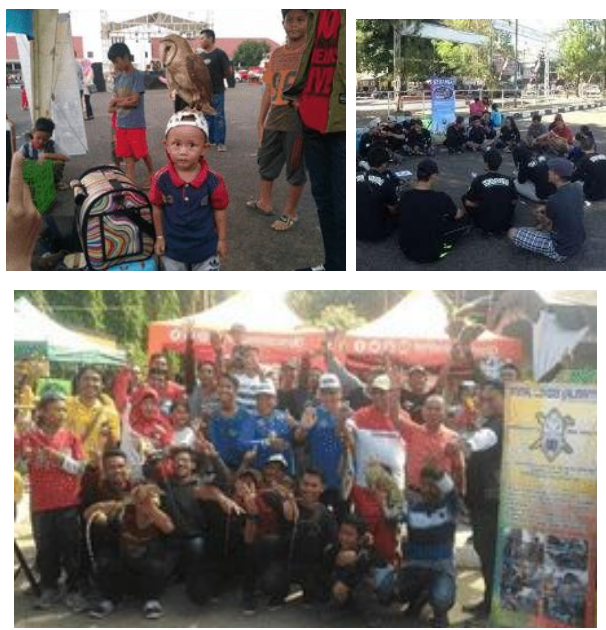

Gambar 3 kegiatan komunitas hewan di lapangan murjani Banjarbaru

Beberapa tahun belakangan ini komunitas-komunitas pecinta hewan tersebut maupun individu pemelihara hewan jarang terlihat melakukan kegiatan rutinnya 
di lapangan Murjani dimungkinkan salah satu faktornya adalah lapangan rumput yang kini berpagar dan peraturan tidak tertulis yang tidak diperbolehkannya hewan menginjak area lapangan rumput tersebut mengakibatkan para komunitas atau individu yang terbiasa membawa hewan peliharaan mereka di area lapangan rumput merasa tergusur, mereka kesulitan mencari tempat yang memperbolehkan membawa hewan peliharaan. Meskipun komunitas-komunitas pecinta hewan seakan hilang hanya meninggalkan nama tidak mengurangi antusias masyarakat untuk memelihara hewan.

\section{Menghilangnya wadah bagi peminat atau komunitas berkumpul maupun} membawa hewan mereka berjalan-jalan, maka diperlukan tempat khusus yang terbuka dan tanpa batasan untuk pemelihara hewan dapat membawa peliharaannya juga dapat disebut tempat yang pet friendly-human friendly. Dengan tingginya minat dan perkembangan hewan kucing di Banjarbaru membuat wadah khusus untuk kucing dan pemeliharanya dirasa sesuai untuk judul tugas akhir ini yaitu cat center, kebutuhan akan fasilitas-fasilitas pendukung kegiatan dalam pemeliharaan juga diperlukan, fasilitas seperti klinik, pet care, pet shop, garden, hall. Jenis ruang/wadah seperti yang disebutkan diperlukan para peminat dan berpotensi sebagai wadah rekreasi, karena dapat berfungsi sebagai platform publik di mana pemilik peliharaan, atau bukan pemilik peliharaan dapat bertemu satu sama lain di lingkungan yang santai dan dapat meningkatkan persahabatan mereka.

\section{PERMASALAHAN}

Berdasar kebutuhan fasilitas bagaimana merancang suatu ruang yang menunjang manusia dan hewan untuk berinteraksi dan berdasar banyaknya peminat hewan kucing yaitu bagaimana rancangan Cat Center di Kota Banjarbaru yang bertujuan mewujudkan wadah untuk hewan peliharaan khususnya kucing dengan fasilitas yang mendukung berdasarkan karakter yang dimiliki kucing?

\section{TINJAUAN PUSTAKA}

\section{A. Definisi Cat Center}

Cat center merupakan tempat dimana kucing dan manusia dapat saling berinteraksi. Hewan kucing mendapatkan kesejahteraannya melalui fasilitas yang diberikan dan manusia mendapat hiburan rekreasi, saling berbagi ilmu mengenai perawatan kucing, tempat berkumpul komunitas pecinta kucing dalam satu tempat.

\section{B. Tinjauan Hewan Kucing}

Kucing mengalami domestikasi dari binatang pemangsa liar menjadi binatang peliharaan diperkirakan terjadi sekitar 10.000 tahun lalu, ketika manusia memasuki jaman bercocok tanam. Kucing mulai bersahabat dengan manusia ketika membantu manusia pada saat itu memburu hama (tikus) yang mengganggu biji-bjian mereka. Hingga sekarang beradaptasi dengan mudah dengan lingkungan yang memungkinkan hewan dapat mendekati dan berkeliaran di sekitar manusia.

1. Jenis Kucing dan Karakternya

Kucing memiliki banyak jenis dari domestik, liar, hingga kucing ras, semuannya tersebar diseluruh dunia. Kucing ras merupakan kucing yang memiliki silsilah yang jelas sedangkan kucing liar/domestik silsilahnya sulit dideteksi karena perkembang-biakannya banyak mengalami evolusi.

Karakter dan Perilaku umum kucing:

- Kucing merupakan hewan penyendiri namun juga dapat berkoloni.

- Kucing hewan yang teritori, juga dapat bersahabat.

- Kucing menyukai suasana hangat dan tidur di bawah hangat sinar matahari, suhu tubuh normal kucing sekitar $39^{\circ} \mathrm{C}$, 
suhu yang baik untuk kucing $22^{\circ}-26^{\circ} \mathrm{C}$ dan kelembaban ideal $40-50 \%$.

- Kotoran kucing kering, kucing suka mengubur kotorannya di tempat berpasir.

- Kucing senang mengintai mangsa dan berburu.

- Kucing tidak terlalu senang air, namun ada beberapa jenis kucing yang senang dengan air.

- Kucing merupakan hewan nokturnal, hewan aktif dimalam hari.

- Kucing merupakan hewan yang bersih. Kucing merawat diri dengan menjilati rambut dengan air lurnya.

- Kucing menyimpan energi dengan cara tidur sering dan lama tidur kucing antara 12 hingga 20 jam per hari.

- Kucing hewan cerdas dan dapat dilatih.

- Kucing memiliki indera pendengaran yang tajam dan kemampuan mencium aroma yang tajam.

- Kucing sangat senang berada di tempat yang lebih tinggi tujuannya untuk menangkap sinyal dan suara.

- Kucing sering menandai areanya dengan mencakar-cakar.

- Kucing mengekpresikan emosi dengan gerakan ekornya juga sebagai cara berkomunikasi.

\section{Fasilitas, Kebutuhan dan Keperluan} Kucing

Kucing mempunyai suatu kebutuhan untuk menunjang keberlangsungan hidup kucing:

- Makan

- Tidur

- Buang air

- Bermain

- Care/Kebersihan

- Berburu

- Kesehatan

Fasilitas untuk memenuhi
- Tempat tidur

Kucing menyukai tidur ditempat yang cukup hangat.

- Tempat makan dan minum

- Mainan kucing Memberikan kucing mainan yang dapat merangsang untuk bergerak, menggigit, dan berburu membantu pembentukan fisik dan mental kucing.

- Tempat menggaruk Kucing mengasah kuku dengan menggaruk sesuatu permukaan kasar seperti kayu, ijuk, sofa, dll.

- Liter Box

\section{Tinjauan Objek Cat Center}

Lingkup pelayanan yang tersedia pada Cat Center di Banjarabru ini, yaitu antara lain:

a. Klinik

Konsultasi dan pengobatan hewan peliharaan kucing dilayani oleh dokter hewan.

b. Pet shop

Penjualan makanan dan aksesoris serta keperluan lain yang menyangkut hewan peliharaan kucing.

c. Pet care

Perawatan tubuh (grooming) hewan kucing.

d. Eventspace

Penyewaan ruang untuk penyelenggaraan lomba dan event lainnya.

e. Playspace

f. Café

\section{PEMBAHASAN}

\section{A. Lokasi}

Lokasi tapak berada di Jl. Ro Ulin (simpang ujung Jl. Trikora) merupakan kawasan yang strategis untuk pembangunan perdagangan, pendidikan, kesehatan, dan pemukiman, dikaji dari aksesbilitas dan penempatan lokasi yang dapat dijangkau kenyamanan kucing: 
dan merupakan kawasan yang mulai dikembangkan.

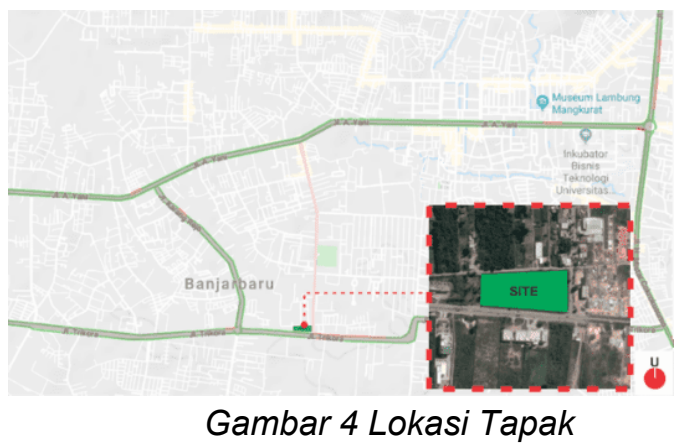

B. Konsep Rancangan

Konsep yang diterapkan dalam rancangan cat center ini adalah konsep attractive dimana konsep ini merupakan penggabungan dari beberapa karakter atau perilaku yang dimiliki kucing, yakni: kelakuan kucing yang menyenangkan dan terkadang bertingkah aneh yang merupakan point of interest kucing, keingintahuannya tinggi, bersahabat, aktif dan suka bermain. Dari konsep tersebut desain yang akan diterapkan merupakan ruang dimana kucing dan manusia dapat berinteraksi dan juga dimana kucing akan merasa nyaman dan dapat bermain di setiap sudut ruangan.

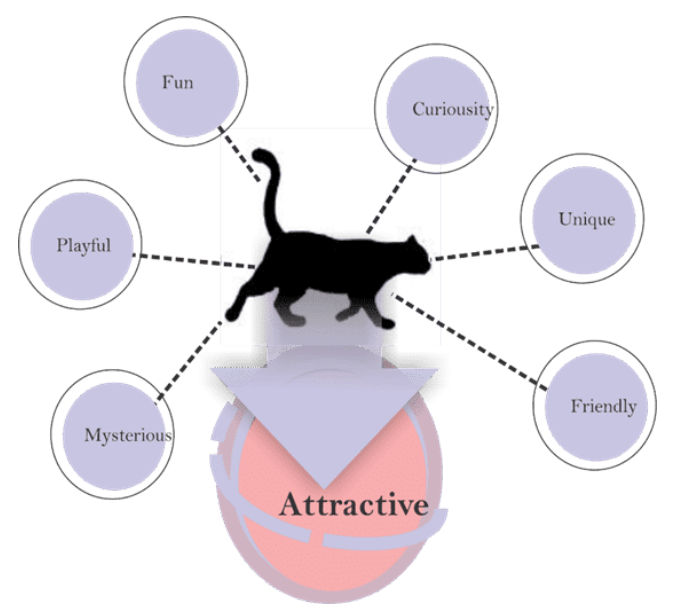

Gambar 5 Konsep Programatik

Attractive berdasar kata sifat dalam bahasa inggris ialah pleasing to the eye or mind especially through beauty or charm.
Attractive dalam bahasa indonesia berarti menarik. Bisa untuk mengungkapkan penampilan atau karakter yang menarik, daya pikat. Attractive bisa disinonimkan dengan 'interesting'.

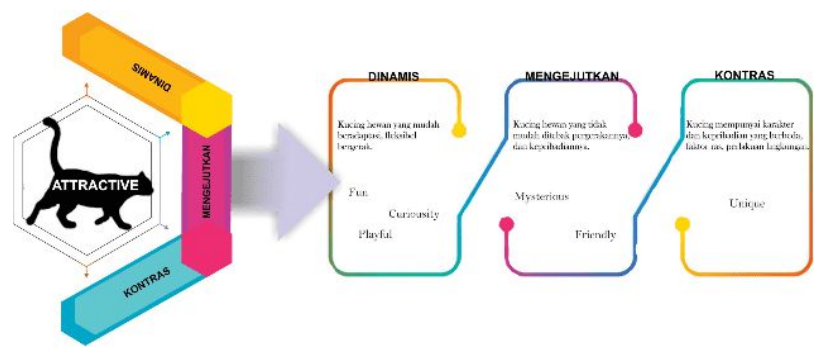

Gambar 6 Konsep Rancangan

1. Dinamis

Kucing hewan yang mudah beradaptasi dengan lingkungan, lincah bergerak dan tubuhnya yang fleksibel. Karena itu dimasukan ke konsep dinamis dalam kamus besar Bahasa Indonesia berarti energik, gerak diharapkan dinamis ini menghasilkan suatu komposisi pada rancangan yang mampu menarik perhatian.

2. Mengejutkan

Kucing sulit ditebak pergerakannya dan kepribadiannya, karena itu adanya sesuatu yang mysterius dan friendly diharapkan menimbulkan rasa penasaran dan ketertarikan pengunjung.

3. Kontras

Kontras dalam kamus besar Bahasa Indonesia berarti memperlihatkan perbedaan nyata (dalam hal warna, rupa, ukuran, dan sebagainya) karena itu penegasan pada warna bangunan diterapkan berdasarkan warna penglihatan kucing diharapkan kekontrasan tersebut menjadikan bangunan cat center ini menonjol sehingga mampu menarik perhatian pengunjung. 


\section{HASIL}

Cat center di Banjarbaru ini merupakan bangunan publik dengan jenis ruang massa banyak yang disesuaikan berdasar sifat ataupun fungsi ruang. Cat center ini dibagi menjaadi 6 zona massa disesuaikan dengan fungsi fasilitas bangunan yaitu,

- Zona semi private: area klinik Fungsinya sebagai tempat perawatan Kesehatan kucing.

- Zona komersil: area pet shop dan cafe

Fungsinya sebagai pemasukan dan daya tarik pengunjung.

- Zona publik area: eventspace dan playspace indoor

Fungsinya sebagai tempat diadakannya acara perkucingan dan bermain.

- Zona semi publik: area adopsi dan pet care

Fungsinya sebagai tempat perawatan kecantikan kucing.

- Zona private: area kantor dan khusus karyawan.

- Zona servis: area mushola dan toilet umum.

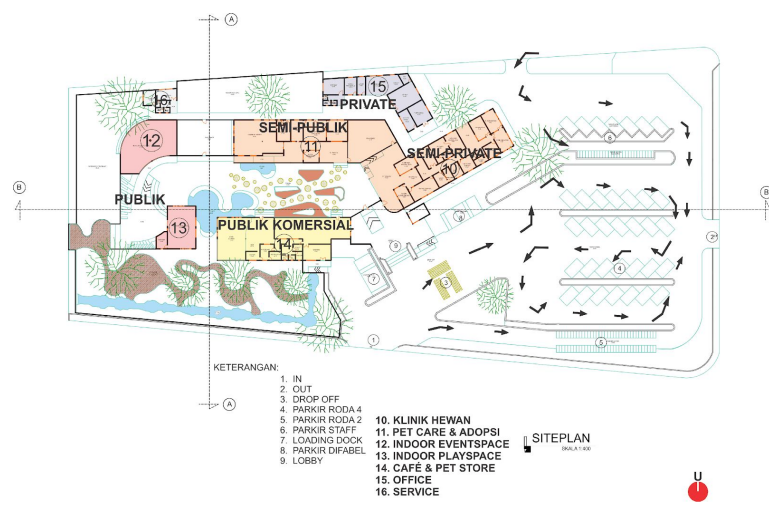

Gambar 7 Zoning Bangunan

Peletakan massa bangunan disesuaikan dengan kepentingan, fungsi dan mobilitas pengunjung. Area klinik mempunyai mobilitas yang cukup sering dikunjungi dengan membawa kucing yang sedang sakit ataupun kucing yang akan divaksin, oleh karena itu area klinik diletakkan bagian awal masuk sebelah kiri lobby dimaksudkan ketika ada hewan yang sedang sakit tidak menyebarkan penyakitnya ke zona lainnya.

Pet care dan adopsi area yang cukup sering dikunjungi namun tidak terlalu mengganggu aktivitas lainnya karena pengunjung pada area ini juga dapat berada di area playspace ataupun café karenanya area semi-publik dan publik-komersial ini diletakkan saling berhadapan. Area private merupakan tempat yang dikhususkan bagi karyawan saja sehingga area ini diletakkan pada bagian belakang massa lainnya dan aktivitas di dalamnya tidak terlihat oleh pengunjung umum.

Area pet store dan cafe diletakkan bagian awal masuk sebelah kanan lobby karena mobilitasnya cukup sering dikunjungi, adanya keluar masuk barang. Area publik eventspace dan playspace menjadi pusat utama interaksi manusia dan kucing letaknya tidak percis berada ditengah namun aktivitasnya cukup terlihat ketika memasuki area massa bangunan. Penyusunan massa bangunan seperti di atas (gambar 7. zoning bangunan) memiliki ruang berupa taman ditengah yang dikelilingi oleh massa diharapkan dapat memudahkan interaksi antara manusia dan kucing.

Ruang interaksi pada kawasan dengan perwujudan fasilitas-fasilitas yang saling terhubung antara satu dengan lainnya. Wujud dari interaksi itu sendiri adalah adanya timbal balik. Pada cat center ini harapannya manusia dapat berekreasi dan hewan mendapat hak kesejahteraannya, seperti hewan membutuhkan tempat tinggal, kesehatan, bermain, kehidupan yang layak dengan adanya fasilitas klinik, grooming, adopsi, playspace. Sementara manusia 
mempunyai salah satu kebutuhan yaitu rekreasi dengan itu fasilitas yang ada seperti playspace, eventspace, café dapat menjadi penghubung antara manusia dan hewan kucing.

Berdasarkan dari analisis karakter kucing dan konsep rancangan yaitu attractive dapat menerapkan analisis konsep tersebut ke dalam rancangan cat center ini,

1. Dinamis

Konsep dinamis didapatkan dari analisis karakter kucing yang mudah beradaptasi dengan lingkungan, tubuhnya yang fleksibel dan kelincahannya dalam bergerak. Dari itu penerapan ke dalam rancangan yaitu dengan menata massa kawasan sesuai dengan zona fungsi ruang memudahkan sirkulasi pengunjung mengenali kawasan (gambar 12. rencana kawasan) dan ruang terbuka yang dibuat luas digunakan sebagai tempat bermain memudahkan aktivitas pengunjung bergerak dengan leluasa.
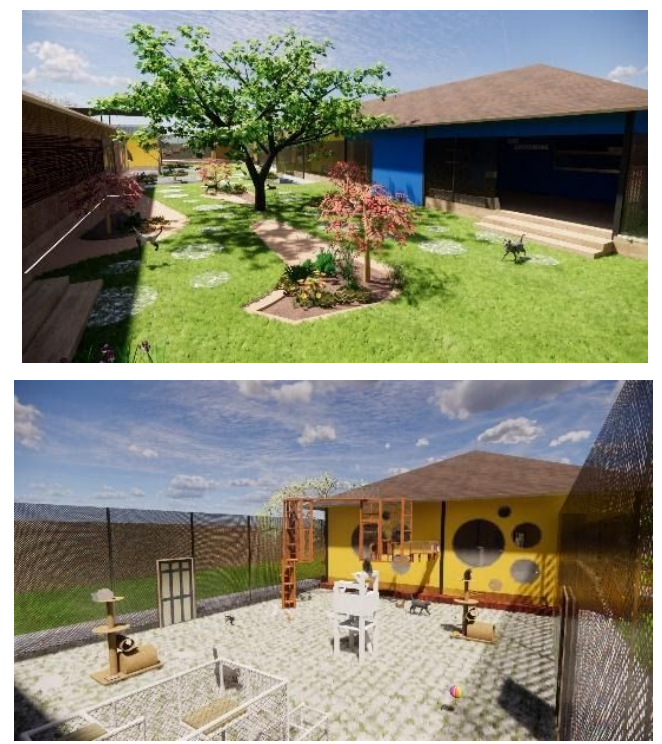

Gambar 8 Playspace

2. Mengejutkan

Konsep mengejutkan didapatkan dari analisis karakter kucing yang tidak mudah ditebak pergerakannya dan kepribadiannya. Penerapan konsep mengejutkan ini dengan diletakkannya spot air/kolam pada kawasan berdasarkan kepribadian kucing yang berbeda satu sama lain dan peletakan area taman yang tersembunyi untuk membuat kesan tidak membosankan (gambar 12. rencana kawasan).

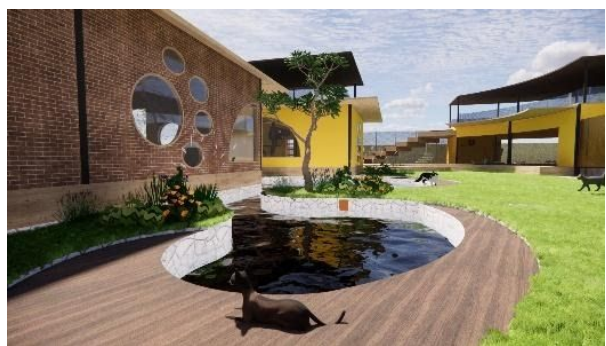

Gambar 9 Kolam

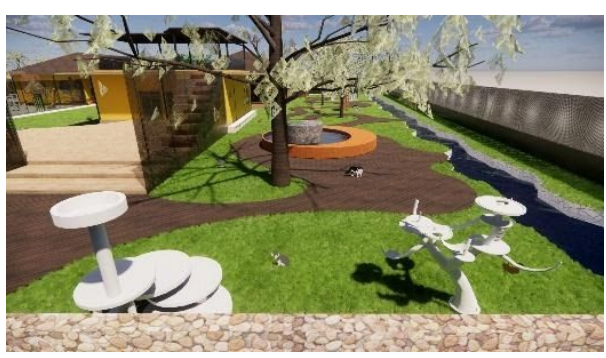

Gambar 10 Outdoor Playspace

\section{Kontras}

Konsep kontras didapatkan dari karakter dan kepribadian kucing yang beragam faktor ras dan perlakuan lingkungan sehingga membuatnya terkesan unik. Penerapan konsep kontras ini dengan memakai perbedaan warna pada massa bangunan yang didapatkan dari warna penglihatan kucing yaitu warna biru dan kuning. 


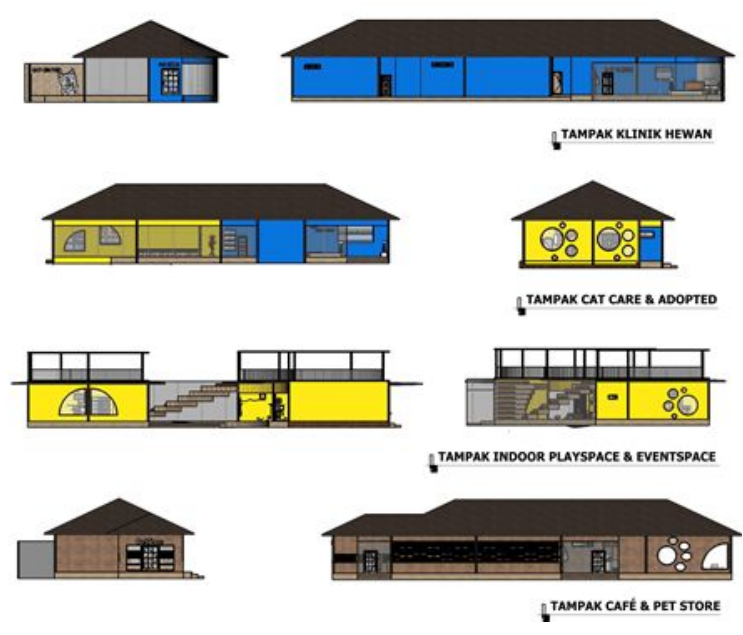

Gambar 11 Tampak Bangunan 

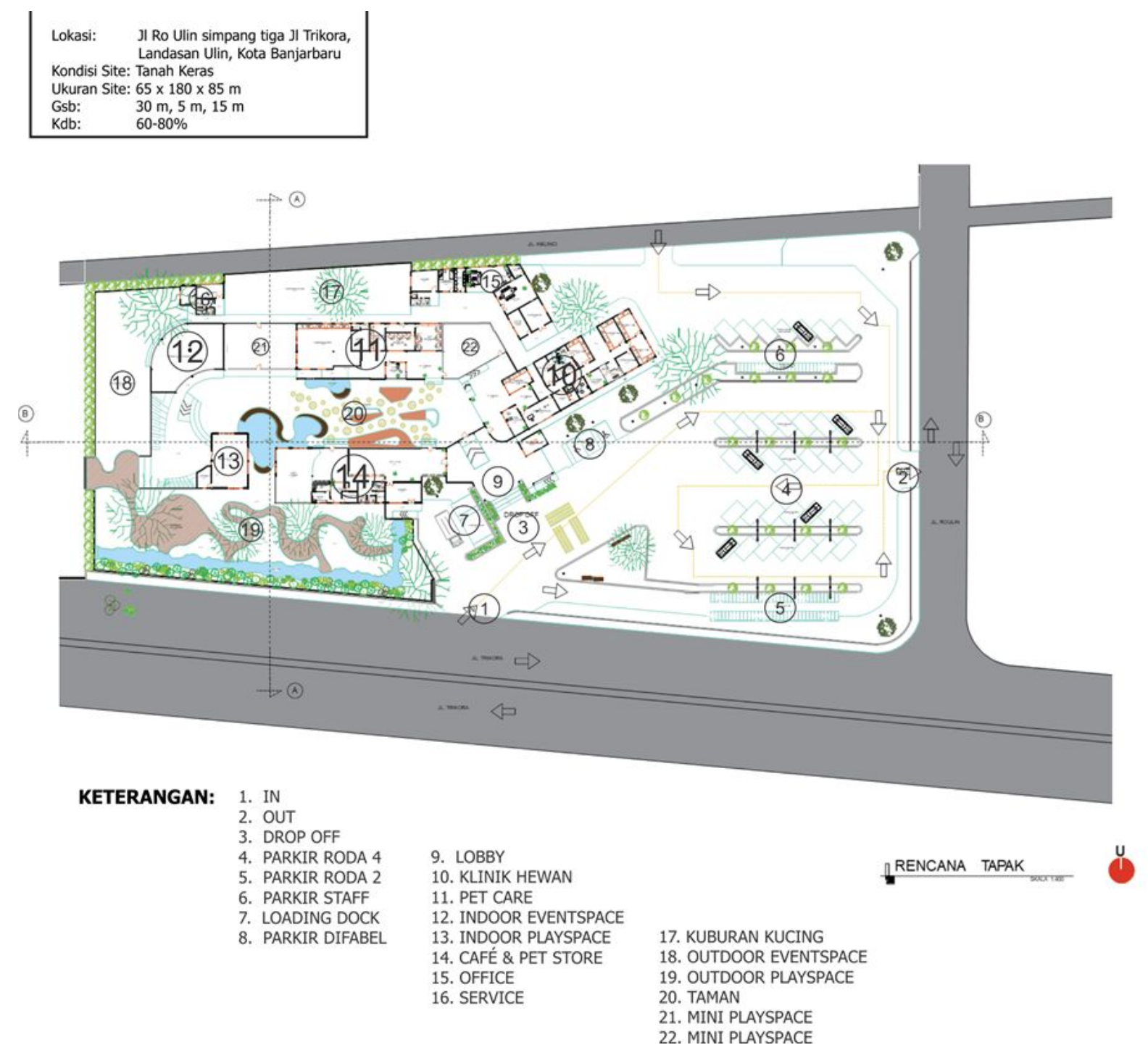

Gambar 12 Rencana Kawasan 


\section{KESIMPULAN}

Cat center merupakan tempat dimana kucing dan manusia dapat saling berinteraksi. Kucing memiliki banyak jenis dari domestik, liar, hingga kucing ras, semuannya tersebar di seluruh dunia. Kucing ras merupakan kucing yang memiliki silsilah yang jelas sedangkan kucing liar/domestik silsilahnya sulit dideteksi karena perkembang-biakannya banyak mengalami evolusi. Lokasi pembangunan cat center berada di Jl. Ro Ulin simpang tiga Jl. Trikora, konsep yang diterapkan dalam rancangan cat center ini adalah konsep attractive dimana konsep ini merupakan penggabungan dari beberapa karakter atau perilaku yang dimiliki kucing, yakni: kelakuan kucing yang menyenangkan dan terkadang bertingkah aneh yang merupakan point of interest kucing, keingintahuannya tinggi, bersahabat, aktif dan suka bermain. Dari konsep tersebut desain yang akan diterapkan merupakan ruang dimana kucing dan manusia dapat berinteraksi dan juga dimana kucing akan merasa nyaman dan dapat bermain di setiap sudut ruangan. Attractive dalam bahasa indonesia berarti menarik, bisa untuk mengungkapkan penampilan atau karakter yang menarik, daya pikat. Ruang interaksi pada kawasan dengan perwujudan fasilitas-fasilitas yang saling terhubung antara satu dengan lainnya.

\section{DAFTAR PUSTAKA}

\section{Referensi Buku dan Jurnal}

Latif, M. (2014). Pet Centre (Pendekatan Pada Konsep Arsitektur Modern Tropis). Surakarta: Universitas Muhammadiyah Surakarta.

Magdalena, J. (2019). Perancangan Omah Kucing di Surabaya.

Puspita Sari, Adelia. (2017) Pusat Perawatan Kucing di Banjarbaru. Banjarbaru: Universitas Lambung Mangkurat
Rachmawati, Murni, Pridany Widya Ad'ha dan Nur Endah Nuffida. (2014). Penerapan Tema Atraktif dalam Rancangan Taman Wisata Brawijaya Malang. Surabaya: Institut Teknologi Sepuluh Nopember.

Sussetyo, Bayu. (2004). Panduan Memelihara Kucing Persia. Jakarta: PT. Agromedia Pustaka.

Suwed, Muhammad dan Rodame M, (2011). Panduan Lengkap Kucing. Depok: Swadaya.

Tri, Lydia. (2013). Pusat Kegiatan Bagi Penyayang Serta Hewan Anjing dan Kucing di Daerah Istimewa Yogyakarta. 